\title{
New Derivative Spectrophotometric Methods for the Determination of Zolpidem Tartrate in Pharmaceutical Dosage Forms
}

\author{
M. MATHRUSRI ANNAPURNA*, B. SAI PAVAN KUMAR, \\ J. RAJ PRAKASH and B. VENKATESH
}

Department of Pharmaceutical Analysis \& Quality Assurance, GITAM Institute of Pharmacy, GITAM University, Visakhapatnam, India mathrusri2000@yahoo.com

Received 2 June 2012 / Accepted 21 June 2012

\begin{abstract}
Two simple, rapid and sensitive first derivative spectrophotometric methods were developed for the determination of zolpidem tartrate in pharmaceutical formulations in phosphate buffer $\mathrm{pH} 8.0$ and borate buffer $\mathrm{pH} 9.0$. Beer's law was obeyed in a concentration range of $1-30 \mu \mathrm{g} / \mathrm{mL}$ in phosphate buffer $\mathrm{pH} 8.0$ and borate buffer $\mathrm{pH} 9.0$ respectively with correlation coefficient of $r^{2}=0.999$ in both the methods. The linear regression equations are found to be $y=0.008 x+0.001$ and $y=0.0094 x+$ 0.0033 in phosphate and borate buffer respectively. The \%RSD for intra-day and inter-day precision studies were found to be 0.23 and 0.56 in phosphate buffer $\mathrm{pH} 8.0$ and 0.63 and 0.68 in borate buffer $\mathrm{pH} 9.0$ respectively which is less than 2.0 indicating that the methods are precise. The \%RSD in accuracy studies was also found to be less than 2.0. The proposed methods are suitable for the determination of zolpidem tartrate in pharmaceutical formulations. No interferences were observed from the excipients in the formulations. The methods were validated according to ICH guidelines.
\end{abstract}

Keywords: Zolpidem Tartrate, Derivative spectrophotometry, Validation

\section{Introduction}

Zolpidem tartrate (ZLT), chemically known as $N, N$, 6-trimethyl-2-ptolyl-imidazo(1,2-a) pyridine-3-acetamide L-(+)-tartrate (2:1) (Figure 1) is an imidazopyridine derivative, is a non benzodiazepine hypnotic agent binds preferentially to one benzodiazepine receptor subtype $\omega$-1 bezodiazepine- 1 thought to mediate hypnotic effects ${ }^{1}$. This combines a rapid onset with a short duration of action.

Zolpidem behaves as a sleep inducer without the muscle relaxant and anticonvulsant effects of the benzodiazepines. The hypnotic actions of zolpidem, like benzodiazepine hypnotics, are mediated at the benzodiazepine recognition site of the GABAA receptor complex $^{2-4}$. However, the neuropharmacological profile of zolpidem is somewhat different 
from that of most benzodiazepines ${ }^{5-6}$. For example, zolpidem binds with low affinity to a $\alpha 5$-containing GABAA -receptor subtypes ${ }^{7}$. Triazolam and diazepam, two benzodiazepines, bind with high affinity to these GABAA -receptor subtypes. Literature survey revealed that zolpidem was determined by liquid chromatographic methods ${ }^{8-15}$ in biological fluids, LC-MS $^{16-17}$, GC $^{18-19}$, GC-MS $^{20}$, capillary electrophoresis ${ }^{21}$, UV-Visible spectroscopy ${ }^{22-23}$ and HPTLC-LC ${ }^{24}$.

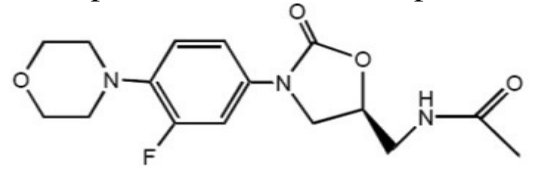

Figure 1. Chemical structure of zolpidem tartrate (ZPT)

In the present study, two novel simple, rapid and cost-effective derivative spectrophotometric methods were developed for the routine analysis of ZPT in pharmaceutical formulations in Phosphate Buffer $\mathrm{pH}$ 8.0 (Method A) and Borate Buffer $\mathrm{pH}$ 9.0 (Method B) and they are validated as per the ICH guideline ${ }^{25-26}$.

\section{Experimental}

A double beam UV-VIS spectrophotometer (UV-1800, Shimadzu, Japan) connected to computer loaded with spectra manager software UV Probe was employed with spectral bandwidth of $1 \mathrm{~nm}$ and wavelength accuracy of $\pm 0.3 \mathrm{~nm}$ with a pair of $10 \mathrm{~mm}$ matched quartz cells. All weights were taken on electronic balance (Denver, Germany). For scanning, the wavelength range selected was from $400 \mathrm{~nm}$ to $200 \mathrm{~nm}$ with medium scanning speed. All experiments were performed at room temperature $(25 \pm 1)^{\circ} \mathrm{C}$.

\section{Reagents and chemicals}

Analytical grade reagents were used. zolpidem tartrate was supplied as gift sample from Dr. Reddy's Labs (India) India. Zolpidem tartrate (ZPT) stock was prepared by dissolving $25 \mathrm{mg}$ of the drug in $25 \mathrm{~mL}$ of methanol in a volumetric flask $(1000 \mu \mathrm{g} / \mathrm{mL})$ and working standard solutions were obtained by proper dilution of this stock solution with Phosphate Buffer $\mathrm{pH} 8.0$ and Borate Buffer $\mathrm{pH} 9.0$ for method A and B respectively.

Zolpidem tartrate (ZPT) is available commercially as tablets with brand names ZOLINOX ® and AMBIEN ® (containing $7.5 \mathrm{mg}$ and $5 \mathrm{mg}$ of the drug content) respectively and twenty tablets from each brand were procured from the local market.

\section{Preparation of stock and sample solution}

The standard solution of zolpidem tartrate was prepared by dissolving accurately about $25 \mathrm{mg}$ of the zolpidem tartrate with methanol in a $25 \mathrm{~mL}$ volumetric flask.

Preparation of phosphate buffer $(0.02 \mathrm{M}) \mathrm{pH} 8.0$

$50 \mathrm{~mL}$ of $0.2 \mathrm{M}$ potassium dihydrogen phosphate was mixed with $46.8 \mathrm{~mL}$ of $0.2 \mathrm{M}$ sodium hydroxide and sufficient water to make up to volume in a 500 volumetric flask.

\section{Preparation of borate buffer $\mathrm{pH} 9.0$}

$6.2 \mathrm{~g}$ of Boric acid was dissolved in $500 \mathrm{~mL}$ of water and $\mathrm{pH}$ was adjusted to 9.0 with $1.0 \mathrm{M}$ sodium hydroxide and diluted with water to $1000 \mathrm{~mL}$. The stock solution was further diluted with phosphate buffer $\mathrm{pH} 8.0$ and borate buffer $\mathrm{pH}$ 9.0. The above solutions were scanned 200$400 \mathrm{~nm}$ against their reagent blank and the absorption spectra were recorded for both methods A and $\mathrm{B}$ respectively. The absorption spectra were transformed in to first derivative spectra. 


\section{Assay procedure for the commercial formulations (Tablets)}

Zolpidem tartarate is available in the local market with brand names zolinox (7.5 $\mathrm{mg}$ of the drug per tablet; Ranbaxy Ltd.) and Ambien (5 mg; $10 \mathrm{mg}$ of the drug per tablet; Dr. Reddy's Labs) were purchased. Twenty tablets were collected from the above two different brands and ZLT equivalent to $25 \mathrm{mg}$ was weighed, extracted with methanol separately, sonicated and make up to volume with methanol in two different $25 \mathrm{~mL}$ volumetric flasks $(1 \mathrm{mg} / \mathrm{mL})$ and filtered. The dilutions were made from this stock with phosphate buffer and borate buffer for method A, B separately and analyzed according to the recommended procedure.

\section{Precision and accuracy}

The precision study was done as per the ICH guidelines by recording the absorbance of six replicates for method A, B and C $(20 \mu \mathrm{g} / \mathrm{mL})$ and the \% RSD was calculated. Accuracy was evaluated as per the ICH guidelines by the percent recovery studies by the addition of $80 \%$, $100 \%$ and $120 \%$ of pure sample solution to the pre-analysed formulation solution. For the present study ZLT drug solution $(5 \mu \mathrm{g} / \mathrm{mL})$ extracted from the formulation was taken and $80 \%, 100 \%$ and $120 \%$ of pure drug solution (i.e. 4,5 and $6 \mu \mathrm{g} / \mathrm{mL}$ ) were added and the $\%$ RSD was calculated.

\section{Results and Discussion}

In method A, the derivative spectrum (Figure 2) shows maxima (230.95 nm) and minima $(254.25 \mathrm{~nm})$ in phosphate buffer $\mathrm{pH} 8.0$ and therefore the amplitude was chosen for the analytical determinations.

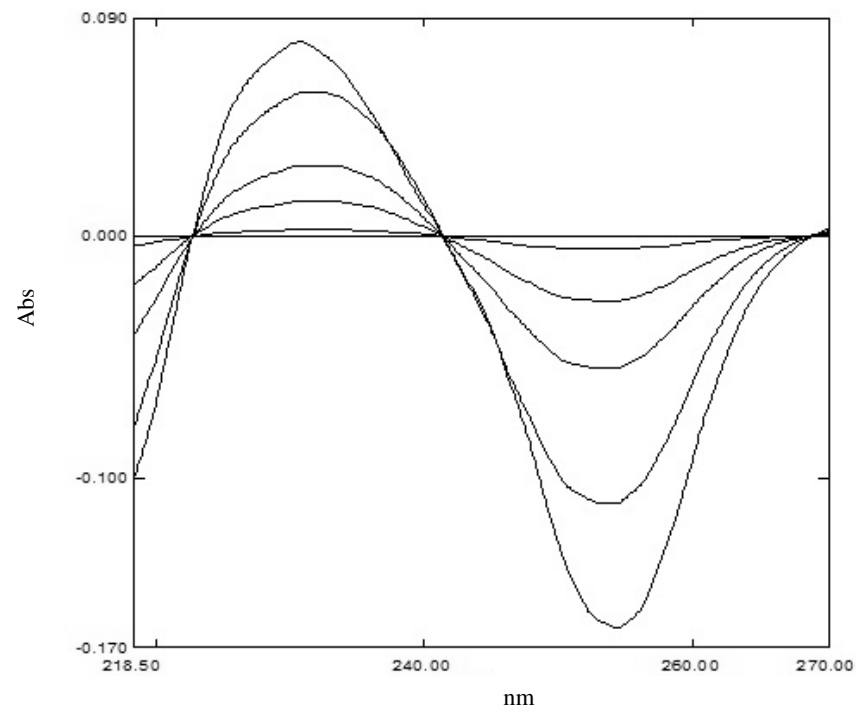

Figure 2. First order derivative overlay spectrum of zolpidem tartrate in phosphate buffer pH $8.0(1-30 \mu \mathrm{g} / \mathrm{mL})$

In method B the derivative spectrum (Figure 3) shows maxima $(231.07 \mathrm{~nm})$ and minima $(254.76 \mathrm{~nm})$ in borate buffer $\mathrm{pH} 9.0$ and hence the amplitude was chosen for the analytical study. A graph was drawn by taking the concentration on the $\mathrm{x}$-axis and the corresponding derivative absorbance on the $\mathrm{y}$-axis for both method A and B. 


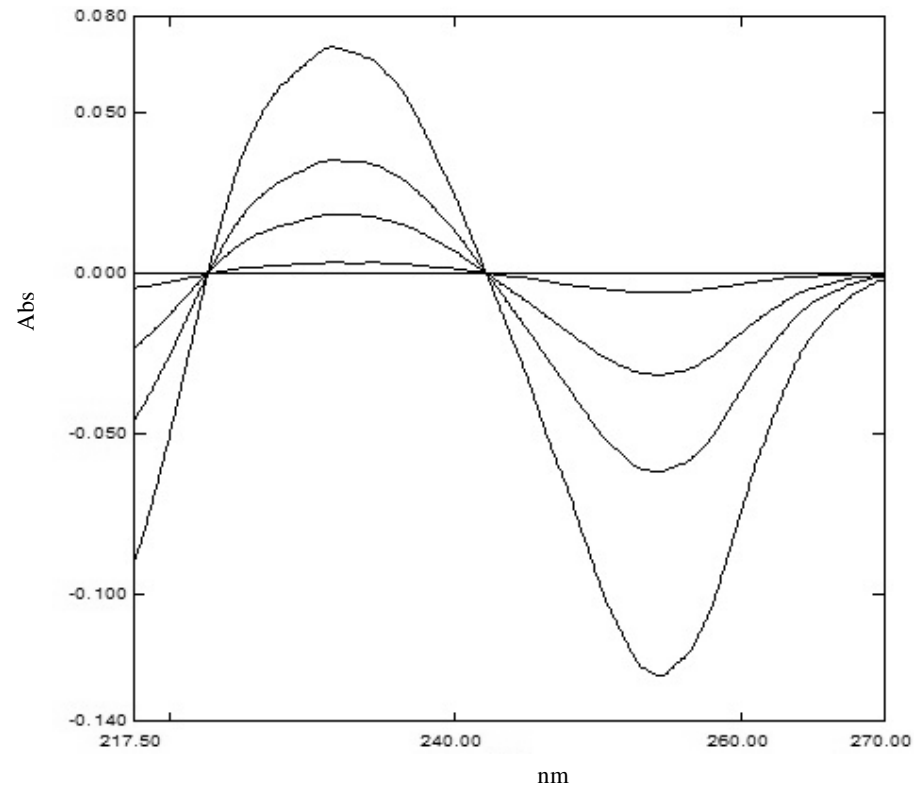

Figure 3. First order derivative spectrum of zolpidem tartrate in borate buffer $\mathrm{pH} 9.0$ $(1-30 \mu \mathrm{g} / \mathrm{mL})$

Beer-Lambert's law was obeyed over the concentration range of $1-30 \mu \mathrm{g} / \mathrm{mL}$ for both method A and B (Figure 4 and 5) respectively. The linear regression equations for method A and $\mathrm{B}$ were found to be $\mathrm{y}=0.008 \mathrm{x}+0.001\left(\mathrm{r}^{2}=0.9999\right)$ and $\mathrm{y}=0.0094 \mathrm{x}+0.0033\left(\mathrm{r}^{2}=0.999\right)$ respectively.

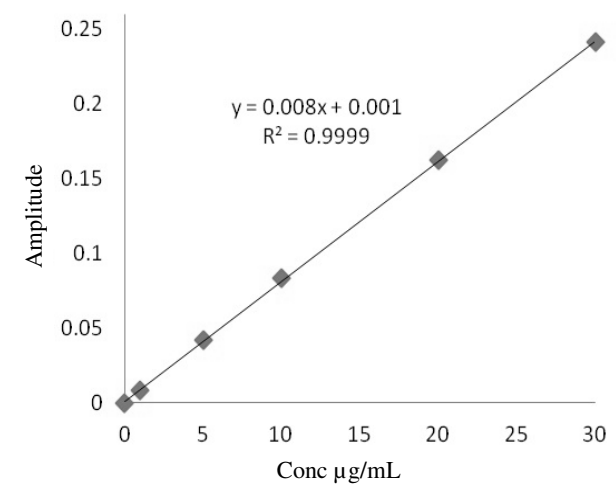

Figure 4. Linearity of zolpidem tartarate in phosphate buffer $\mathrm{pH} 8.0$

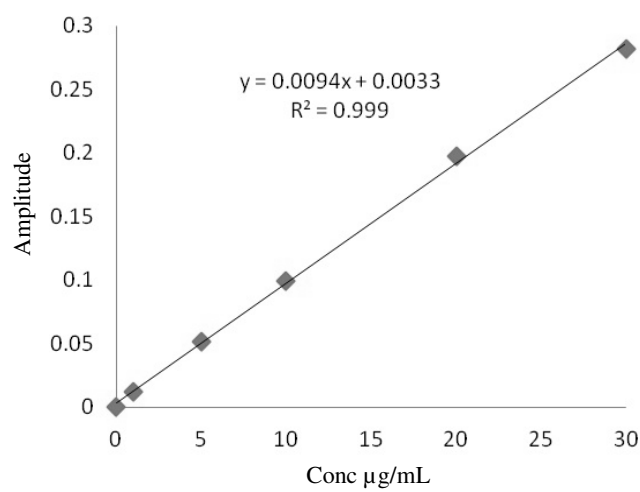

Figure 5: Linearity of zolpidem tartarate in borate buffer $\mathrm{pH} 9.0$

The $\%$ RSD values in precision studies were found to be less than $2 \%$ in both methods A and $\mathrm{B}$ indicating that the method is more precise. The \% RSD values in accuracy studies were also found to be less than $2 \%$ in both methods A and B indicating that the method is more accurate. The optical characteristics were shown in Table 1 . The $\%$ recovery was found to be 99.7-99.88 and 99.46-99.91 for methods A and B respectively in marketed formulations (Table 2). 
Table 1. Optical characteristics of Zolpidem Tartrate

\begin{tabular}{|c|c|c|}
\hline Parameters & Method A & Method B \\
\hline$\lambda . \mathrm{nm}($ Amplitude $)$ & $230.95-254.25$ & $231.07-254.76$ \\
\hline Beer-Lambert's range, $\mu \mathrm{g} / \mathrm{mL}$ & $1-30$ & $1-30$ \\
\hline Slope & 0.008 & 0.0094 \\
\hline Intercept & 0.001 & 0.0033 \\
\hline Correlation coefficient & 0.9999 & 0.999 \\
\hline \multicolumn{3}{|c|}{ Precision (RSD, \%) } \\
\hline Intra-day $(n=3)$ & 0.23 & 0.63 \\
\hline Inter-day $(\mathrm{n}=3)$ & 0.56 & 0.68 \\
\hline Accuracy ( $\%$ recovery) & $99.7-99.88$ & $99.46-99.91$ \\
\hline
\end{tabular}

Table 2. Analysis of zolpidem tartrate commercial formulation (Tablets)

\begin{tabular}{cccccccc}
\hline \multirow{3}{*}{ Brand } & $\begin{array}{c}\text { Labeled } \\
\text { Amount, } \\
\text { mg }\end{array}$ & \multicolumn{2}{c}{$\begin{array}{c}\text { *Amount } \\
\text { Obtained, mg }\end{array}$} & \multicolumn{2}{c}{ \% Recovery } & \multicolumn{2}{c}{$\%$ RSD $^{*}$} \\
\cline { 3 - 9 } & & \multicolumn{2}{c}{ Method } & \multicolumn{2}{c}{ Method } & \multicolumn{2}{c}{ Method } \\
\hline Zolinox & 7.5 & 7.49 & B & A & B & A & B \\
Ambien & 5.0 & 4.99 & 4.97 & 99.87 & 99.73 & 0.36 & 0.55 \\
\hline \multicolumn{4}{c}{ "Mean of three determinations } & 99.40 & 0.48 & 0.67 \\
\hline
\end{tabular}

\section{Conclusion}

The proposed methods are simple, precise and accurate and can be applied for the determination of zolpidem tartrate (ZPT) in pharmaceutical formulations successfully.

\section{Acknowledgment}

The authors are grateful to M/S GITAM University for providing necessary research facilities and to Dr. Reddy's Labs (India) for providing the gift samples of the drug.

\section{References}

1. Budavari S, Editor, The Merck Index. $12^{\text {th }}$ Ed., White house Station (NJ): Merck and Co. Inc; 1996, 10322.

2. Walker R and Edwards C, Clinical Pharmacy and Therapeutics, $2^{\text {nd }}$ Ed., Churchill Livingstone United Kingdom; 1999, 399.

3. Haefely W E, Eur Arch Psychiatr Neurol Sci., 1989, 238(5-6), 294-301.

4. Sauvanet J P, Langer S Z and Morselli P L, Imidazopyridines in sleep disorders. Raven Press, New York, 1988, 175-81.

5. Arbilla S, Depoortere H, George P and Langer S, Naunyn-Schmiedeberg's Arch Pharmacol., 1985, 330, 248-251

6. Benavides J, Peny B, DuBois A, Perrault G, Morel E, Zivkovic B and Scatton B, $J$ Pharmacol Exp Ther., 1989, 245, 1033-1041.

7. Besnard F, Avenet P, Itier V, Granger P, Partiséti M, Depoortere H, Graham D and Langer S Z, In: Freeman H, Puech A J and Roth T, (Eds)., Zolpidem: An update of its pharmacological properties and therapeutic place in the management of insomnia. Elsevier; Paris 1996, 21-32.

8. Lavianaa L, Mangasa C, Fern'andez-Mar'ib F, Bayodb M and Blancoa, J Pharm Biomed Anal., 2004, 36, 925-928. 
9. Paula R. Ring and James M. Bostick, J Pharm Biomed Anal., 2000, 22, 495-504.

10. Tracqui A, Kintz P and Mangin P, J Chromatogr B: Biomed Sci Appl., 1993, 616(1), 95-103.

11. Ascalone V, Flaminio L, Guinebault P, Thenot J P and Morselli P L, J Chromatogr B: Biomed Sci Applications, 1992, 581(2), 237-250

12. Gock S B, Wong S H Y, Nuwayhid N, Venuti S E, Kelley P D, Teggatz J R and Jentzen J M, J Anal Toxicol., 1999, 23, 559-562.

13. Ptáček P, Macek J and Klíma J, J Chromatogr B:Biomed Sci Applications, 1997, 694(2), 409-413

14. Qiao Wang, Lei Sun and Chyan E. Lau, J Chromatogr B: Biomed Sci Applications, 1999, 734(2), 1999, 299-305.

15. Guinebault P, Dubruc C, Hermann P and Thénot J P, J Chromatogr B: Biomed Sci Appl., 1986, 383, 206-211.

16. Kintz P, Villain M and Ludes B, J Chromatogr B, 2004, 811(1), 59-63.

17. Giroud C, Augsburger M, Menetrey A and Mangin P, J Chromatogr B, 2003, 789(1), 131-138.

18. Gaillard Y, Gay-Montchamp J P and Ollagnier M, J Chromatogr., 1993, 622(2), 197-208.

19. Stanke F, Jourdil N, Bessard J and Bessard G, J Chromatogr B: Biomed Sci Appl., 1996, 675(1), 43-51.

20. Keller T, Schneider A and Tutsch-Bauer E, Forensic Sci Int., 1999, 106(2), 103-108.

21. Hempel G and Blaschke G, J Chromatogr B: Biomed Sci Appl., 1996, 675(1), 131-137.

22. Patil K.S, Pore Y V and Bhise S B, J Pharm Sci Res., 2010, 2(1), 1-4

23. Rajiv Chomwal, Amit Kumar and Anju Goyal, J Pharm Bioall Sci., 2010, 2(4), 365-368.

24. El Zeany B.A, Moustafa A.A and Farid N F, J Pharm Biomed Anal., 2003, 33(3), 393-401.

25. Validation of Analytical Procedures: Methodology (Q2B), ICH Harmonized Tripartite Guidelines, Geneva, 1996.

26. International Conference on Harmonization of Technical Requirements for the Registration of Pharmaceutical for Human Use: Validation of Analytical procedures, Text and methodology - Q2 (R1), 2005. 